\title{
RNF139 wt Allele
}

National Cancer Institute

\section{Source}

National Cancer Institute. RNF139 wt Allele. NCI Thesaurus. Code C50388.

Human RNF139 wild-type allele is located within 8q24 and is approximately $14 \mathrm{~kb}$ in length. This allele, which encodes RING finger protein 139, is involved in mediating ubiquitination. RNF139 gene dysfunction is associated with renal cell carcinoma. 